\title{
Theoretical, Legal and Organizational Foundations of Volunteer Activities in the Field of Social Adaptation of Individuals Sentenced to Non-Custodial Punishment in Russia
}

\author{
SERGEI L. BABAYAN \\ Research Institute of FSIN Russia, Moscow, Russian Federation \\ Vologda Institute of Law and Economics of FSIN Russia, Vologda, Russian \\ Federation \\ ORCID: https://orcid.org/0000-0001-8712-0192, e-mail: bsI09@mail.ru
}

NIKOLAI V. OL'KHOVIK

Research Institute of FSIN Russia, Moscow, Russian Federation

National Research Tomsk State University, Tomsk, Russian Federation

ORCID: https://orcid.org/0000-0002-7150-7234, e-mail: lawtsu@rambler.ru

\section{SVETLANA A. FADEEVA}

Research Institute of FSIN Russia, Moscow, Russian Federation

Nizhny Novgorod Institute for Education Development, Nizhny Novgorod, Russian Federation

ORCID: https://orcid.org/0000-0002-7150-7234, e-mail: fadeeva1607@gmail. com

IRINA A. LAKINA

Research Institute of FSIN Russia, Moscow, Russian Federation

ORCID: https://orcid.org/0000-0002-5342-2886, e-mail: shumik.88@mail.ru

\section{LIDIYA P. PITKEVICH}

Research Institute of FSIN Russia, Moscow, Russian Federation

ORCID: https://orcid.org/0000-0003-2040-0960, e-mail: Lida-19832008@ yandex.ru

\section{Abstract}

Introduction: the article investigates theoretical, legal and organizational foundations for participation of volunteers in the social adaptation of individuals convicted to noncustodial punishments. Aim: we review theoretical, legal and organizational foundations of the work of volunteers in the field of execution of sentences in Russia and foreign countries and show the prospects for their participation in the social adaptation of individuals convicted without isolation from society in our country. Methods: comparative legal, empirical methods of description, interpretation, theoretical methods of formal and dialectical logic, private scientific methods: legal-dogmatic and method of interpretation of legal norms. Results: in the life of those convicted to non-custodial punishments, volunteerism performs mobilization, regulatory, stimulating, communicative functions, as well as the functions of socialization and self-affirmation. Conclusions: we propose to supplement the list of activities in respect of which the federal executive authorities, executive authorities of constituent entities of the Russian Federation, and local government bodies approve the procedure for interaction between state and municipal institutions and volunteers, with one more type of activity such as assistance in the work of institutions and bodies executing sentences, participation in the reformation of convicts and their social adaptation. We substantiate the proposals on assigning the state authorities of the Russian Federation, constituent entities of the Russian Federation, and local government bodies the obligation to provide organizational, informational, 
methodological and other support to the subjects of voluntary (volunteer) activities that promote the work of institutions and bodies executing sentences, to take into account the voluntary (volunteer) activity of the convicted person when determining the degree of their reformation, recognition of the active participation of the person convicted to noncustodial punishment in voluntary (volunteer) activities as the basis for applying incentive measures to such convicts.

Keywords: penal law; non-custodial punishments; the public; probation inspectorates; volunteers.

12.00.08 - Criminal law and criminology; penal law.

F or c it a t i o n: Babayan S.L., Ol'khovik N.V., Fadeeva S.A., Lakina I.A., Pitkevich L.P. Theoretical, legal and organizational foundations of volunteer activities in the field of social adaptation of individuals sentenced to non-custodial punishment in Russia. Penitentiary Science, 2021, vol. 15, no. 3, pp. 621-627. DOI 10.46741/2686-9764-2021-15-3-621-627.

\section{Introduction}

Volunteerism is one of the tools for the social, economic and spiritual development of civil society. A developed institution of volunteerism is a characteristic feature of a stable social system. New opportunities for self-realization of citizens, as well as the dissemination of relevant practices in social development are among the target priorities of volunteerism. A volunteer is a person who voluntarily participates in any activity, and volunteerism is the participation of a person in any organization or movement on their own volition and on their own accord.

Volunteering attracts the attention of researchers from different fields of science. I.L. Korneeva [4], O.I. Kholina [14], L.I. Yakobson [3; 17] study volunteerism as one of the practices of civil society; L.I. Nikovskaya, V.N. Yakimets [5], A.V. Sokolov [11] study volunteerism as a practice of forming public interests; A.A. Klepikova [2], M.V. Pevnaya [7], Z.Kh. Saralieva [8; 9] study volunteerism in the context of involvement in social work, etc. However, unfortunately, relatively few theoretical studies are devoted to the influence of volunteerism on the process of reformation and socialization of convicts. If necessary, we can rely only on the works of L.I. Sikorskaya [10], N.V. Tarasova [12], which reveal pedagogical and educational aspects of volunteerism.

Materials and methods

Volunteerism, which takes place among those sentenced to non-custodial punishments, is not only the implementation of socially oriented activities to address social problems. A number of approaches are potentially feasible when volunteerism is determined as a methodological basis for the socialization of the individuals under consideration:

- personality-oriented approach that considers a convicted person participating in voluntary activities as an active subject of their own re-socialization and reformation based on personal potentials and opportunities;

- information and educational approach based on the principle "from equal to equal", when convicts can provide all possible support and assistance to each other;

- axiological approach justifying the value component of voluntary activity for the life and well-being of the convicted person;

- system approach that considers volunteerism as an organizational integrity that combines goals, resources, processes, etc.

The Research Institute of the Federal Penitentiary Service of Russia conducted a survey of employees from 30 territorial bodies of the Federal Penitentiary Service of Russia so as to summarize positive practices related to the work of voluntary (volunteer) organizations (teams, groups, links) among those sentenced to punishments and measures of a criminal nature without isolation from society. We emphasize that the work on involving volunteer organizations in the process of socialization of convicts under consideration is carried out in all the bodies involved in the study.

\section{Results and discussion}

Volunteerism as a tool of positive influence on those sentenced to non-custodial punishments seems to be a rather complex socio-cultural phenomenon. Its main functions in the life of convicts are: mobilization, regulatory, stimulating, communicative, as well as the functions of socialization and self-affirmation.

We should note that volunteerism has a huge socio-pedagogical potential, therefore, the use of this resource for the reformation and re-socialization of convicts can both cause immediate positive social effects and have delayed educational results.

The Concept for development of volunteerism in the Russian Federation until 2025, 
approved by the Resolution of the Government of the Russian Federation no. 2950-r dated December 27, 2018 (hereinafter referred to as the Concept of Volunteerism), point out that promoting the development and dissemination of voluntary (volunteer) activities is among priority areas of social and youth policy. The Constitution of the Russian Federation lays down the legal basis for the implementation of voluntary (volunteer) activities [13], and the practice of volunteerism is built, as a rule, on the basis of Federal Law 135-FZ dated August 11, 1995 "On charitable activities and volunteerism" (hereinafter - Federal Law 135) and the Concept of Volunteerism.

When defining the legal basis for the activity of volunteers in the process of social adaptation of individuals sentenced to non-custodial punishment we find it necessary to recall the definition of the term "voluntary activity". So, voluntary (volunteer) activity is understood as free-will activity in the form of gratuitous performance of works and (or) provision of services for the purposes that are exhaustively provided for in Paragraph 1 of Article 2 of Federal Law 135.

Non-governmental associations can assist in the work of institutions and bodies executing punishments; they also take part in the reformation of convicted persons (Article 23 of the Criminal Code of the Russian Federation). There arises a natural question concerning the goals of volunteer activity relevant for the work of volunteers with convicts and the targets of assistance in the work of institutions and bodies executing sentences.

It is known that those sentenced to punishments and measures of a criminal-legal nature that are not related to isolation from society are registered with probation inspectorates of the territorial bodies of the Federal Penitentiary Service of Russia. Since the goals of such punishments are to reform convicts and prevent the commission of new crimes, there is no doubt that priority in volunteerism is given to its preventive function as a way to prevent socially dangerous conduct.

It is worth emphasizing that convicts registered with probation inspectorates are heterogeneous in their socio-demographic, sociorole, moral-psychological, criminal-legal and criminal-executive characteristics, and the process of determining crime and other socially dangerous forms of human conduct includes many interrelated factors [6]; therefore, the goals of voluntary (volunteer) activity listed in Paragraph 1 of Article 2 of Federal Law 135 remain relevant when applied to the work with individuals sentenced to non-custodial punishments. Most of these goals seem to be directly correlated with the terms "social adaptation" and "resocialization". These terms are contained in Federal Law 182-FZ of June 23, 2016 "On the basics of the crime prevention system in the Russian Federation". It is in this document that the term "social adaptation" is used; and it is defined as a set of measures aimed at providing assistance to persons in a difficult life situation (who include persons serving noncustodial sentences) in the implementation of their constitutional rights and freedoms, as well as assistance in labor and household arrangements (Article 24).

In accordance with Article 5 of Federal Law 135 , participants in voluntary (volunteer) activities are volunteers, organizers of voluntary (volunteer) activities and voluntary (volunteer) organizations. It also defines that volunteers are individuals who carry out voluntary (volunteer) activities for the purposes specified in Paragraph 1 of Article 2 of this federal law, or for other socially useful purposes. Organizers of voluntary (volunteer) activities are non-profit organizations and individuals who attract volunteers on a permanent or temporary basis to carry out voluntary (volunteer) activities, and who manage the activities of volunteers.

In order to develop volunteerism, territorial bodies of the Federal Penitentiary Service of Russia constantly interact with various volunteer organizations that help to engage convicts serving non-custodial sentences in volunteer activities. When organizing preventive work with such individuals, including minors, it is of great importance to assist them in solving social problems (medical treatment, continuing education, employment, providing legal, material and other assistance).

Currently, more than 70 agreements on cooperation with regional centers of the Association of Volunteer Centers, 76 agreements with the regional centers of the National Parent Association and 572 agreements with voluntary (volunteer) movements and youth non-governmental associations have been concluded.

During 2020, staff of the penal system, together with volunteer organizations, conducted more than a thousand events to provide social support to minors sentenced to non-custodial punishments, which covered more than 2,600 such individuals.

The results of a survey conducted by the Research Institute of the Federal Penitentiary Ser- 
vice of Russia in May 2021 indicate that 100\% of the territorial bodies of the Federal Penitentiary Service of Russia that participated in it are working to attract volunteer organizations to the process of socialization of those sentenced to non-custodial punishments.

For example, the Directorate of the Federal Penitentiary Service of Russia for the Vologda Oblast, using the information from the unified information system "Volunteers of Russia", determined the events in which convicts serving non-custodial sentences and penal officers can participate in all municipal entities of the Oblast. Relevant agreements have been concluded with volunteer units and voluntary movements at the municipal level. In June 2020 in the municipal state institution "Cherepovets Youth Center", a meeting of juvenile convicts with a representative of the Volunteer School was organized; at the meeting, one spoke about the activities of volunteer organizations and the ways of participating in the volunteer movement. Minors who are registered with probation inspectorates were given a booklet with information from Cherepovets Youth Center, which contains information about existing associations of the volunteer organization, ongoing actions and events, and contact details.

Probation inspectorates of the Directorate of the Federal Penitentiary Service of Russia in the Samara Oblast signed agreements with the volunteer corps "Istochnik dobra" (source of good) and the volunteer movement "Volontery pobedy" (volunteers of victory). Probationers together with representatives of voluntary (volunteer) organizations provided household assistance to disabled people and physically challenged people in the second quarter of 2020 in Chelno-Vershinsky and Shentalinsky districts.

We think that the when convicts serving noncustodial sentences are placed in the conditions of ordinary life organized by trained specialists, it contributes to reducing recidivism among this category of persons. Probation inspectorates have the opportunity to adjust the applied models of socio-pedagogical and educational work with convicts. However, the effectiveness of these processes is ensured only by the availability of the necessary regulatory and legal framework and socio-economic resources. In addition, cooperation between various social institutions in working with individuals sentenced to non-custodial punishments can make an invaluable contribution to their social adaptation. This is emphasized by the global and European standards in the field of execution of non-custodial sentences. For example, the Recommendation of the Committee of Ministers of the Council of Europe on the Council of Europe Probation Rules 2010, taking into account the diversity of the functions performed by this agency, establishes the principle of interaction with other state bodies and organizations for the purpose of providing assistance to offenders (Paragraph 12). The same provision is contained in Paragraph 15 of the European Rules for Juvenile Offenders.

Moreover, a comparative legal study of the functions performed by probation services in Europe convincingly proves that they are implemented, as a rule, with mandatory interaction with other institutions [16, p. 236; 18]

For example, the probation service in Germany organizes the preparation of convicts for release, provides them with employment assistance and housing together with volunteers. As a rule, volunteering is carried out in two types: trusteeship (individual) and cooperation (group). Individual volunteering implies individual work on the part of a member of the public with a specific convict within the framework of a volunteer program, and group volunteering includes the work of a volunteer with a group of convicts (for example, a group organization of sports and leisure) [3, pp. 84-85]. In Germany, a program is being implemented to recruit and train volunteer assistants, among other things, through special courses, seminars and conferences.

In Latvia, the State Probation Service has started to attract volunteers to its work since 2017. Young people aged from 14 to 25 can participate in the volunteer program; older people who, for example, will work with a convict, who has spent more than five years in prison, can also participate as an exception. There are no age restrictions for volunteers. During supervision, the probation service tries to find a volunteer who could be interesting to the convict due to common hobbies, needs and skills. The agreement with the convicted person is concluded for the period of supervision and is valid, as a rule, from six months to four years. Anyone over the age of 18 can apply by filling out a questionnaire on the website of the State Probation Service. The questionnaire is sent to the applicant's place of residence, and after that an interview is held with them. A probation service client (a convicted person) fills out a questionnaire in which they point out what they are currently doing and what they want to learn. 
The probation officer tries to identify risks and problems that need to be worked out. After filling out the questionnaire, the probation officer consults with the coordinator and evaluates the possibility of finding a suitable volunteer. After a while, a meeting is held, in which a coordinator, a volunteer and a client of the probation service participate. At the meeting, the rules of conduct are discussed and contacts are exchanged. The probation service client and the volunteer agree on their first meeting. The volunteer must communicate with the convicted person for at least eight hours a month, including telephone conversations, which is reflected in the meeting diary kept by the volunteer [1].

Federal laws contain provisions that are potentially applicable to the category of convicts under consideration. Thus, Article 24 of the federal law "On the basics of the crime prevention system in the Russian Federation" provides that social adaptation (including those sentenced to non-custodial punishment) occurs through:

1) "promoting the activities of organizations that provide jobs to persons in need of social adaptation, as well as to persons who have undergone treatment for drug addiction, alcoholism and substance abuse and rehabilitation;

2) providing social services to persons in need of social adaptation, including persons in difficult life situations, in social service organizations in accordance with Federal Law 442-FZ of December 28, 2013 "On the basics of social services for citizens in the Russian Federation", as well as regulations of state authorities of constituent entities of the Russian Federation;

3) providing state social assistance on the basis of a social contract in accordance with Federal Law 178-FZ of July 17, 1999 "On state social assistance";

4) involving non-governmental associations in assisting persons in need of social adaptation".

Article 17.3 of Federal Law 135 defines the powers of state authorities of the Russian Federation, state authorities of RF constituent entities and local government bodies in the field of volunteerism. The general requirements for the procedure for interaction of federal, regional and local executive authorities, state and municipal institutions subordinate to them, and other organizations with subjects of voluntary (volunteer) activity are established by the Government of the Russian Federation in Resolution 1425 dated November 28, 2018. This document sets out the procedure for interaction; however, the list of activities for which it is approved is currently limited to only a few areas. Despite the fact that the identified areas of interaction apply to convicts registered with probation inspectorates, we consider it necessary to supplement the existing list with another item: assistance in the work of institutions and bodies executing sentences, participation in the reformation of convicts. In our opinion, it is necessary to emphasize the importance of ensuring public safety from criminal threats, providing for the possibility of stimulating the participation of volunteers in working with those sentenced to non-custodial punishment.

The creation and development of a voluntary movement of convicts will allow them to feel a connection with society and mitigate negative aspects of serving a sentence.

Taking into account the fact that the Criminal Code of the Russian Federation does not stipulate the right of convicts to participate in volunteerism (volunteering), it seems appropriate to indicate in Paragraph 6.2 of Article 12 of the Penal Enforcement Code of the Russian Federation that convicts can participate in volunteer activities, provided that appropriate agreements are concluded by institutions and bodies executing punishments. It should also be noted that the active participation of convicts in volunteering is taken into account when the degree of their reformation is determined and the means of encouraging influence are applied to them. In addition, Article 23 of the Penal Enforcement Code of the Russian Federation should provide that public associations, centralized religious organizations, as well as participants in voluntary (volunteer) activities can contribute to the work of institutions and bodies executing sentences and take part in the reformation of convicts.

It is advisable to stimulate the activity of convicts as part of voluntary (volunteer) organizations by applying incentive measures, incentive norms and institutions to them. Article 57 of the Penal Enforcement Code of the Russian Federation should indicate that active participation in voluntary (volunteer) activities is one of the factors contributing to the application of incentive measures to those sentenced to restriction of freedom. It is necessary to take this activity into account when determining the degree of reformation, for example, when deciding on the cancellation of a suspended sentence and the removal of a criminal record in relation to conditionally convicted persons who are registered with a probation inspectorate. 


\section{Conclusions}

Having analyzed the theoretical, legal and organizational foundations of the work of volunteers in the field of social adaptation of persons serving non-custodial punishments, we can say that a number of important aspects regarding the work of probation inspectorates should be revised. Among the priority areas, we should name the following:

- providing support to the organizers of voluntary (volunteer) activities, voluntary (volunteer) organizations, among other things, in their interaction with state and municipal institutions and other organizations;

- popularization of voluntary (volunteer) activities;

- promoting participation in municipal programs and events aimed at supporting volunteerism;

- support in the field of training and education of employees and volunteers in case it is impossible to carry out voluntary (volunteer) activities without special training;

- participation in the methodological support of local government bodies on the elaboration and implementation of measures for development of volunteerism in municipalities;

- promoting the activity of convicts as volunteers (to take this activity into account when assessing the degree of reformation of a convict, namely, when canceling a suspended sentence and removing a criminal record) for the implementation of successful reformation impact and the formation of a positive social portfolio of convicts.

It seems that all the above-mentioned proposals to improve the assistance of volunteers in the work on the socialization of convicts can become a catalyst for the further development of volunteerism in the field of execution of noncustodial sentences, thereby contributing to the prevention of offenses and achieving the goals of criminal punishment.

\section{REFERENCES}

1. Interview with a specialist of the Latgale regional Probation Department of Latvia Sanita Suveizda. Our city: News of Daugavpils: website. Available at: https://gorod.Iv/novosti/307894-sluzhba-probatsii-privlekaet-volonterov-dlyasotsializatsii-prestupnikov\#ixzz6mu8dsaB9 (accessed June 1, 2021). (In Russ.).

2. Klepikova A.A. Volunteers of a charitable organization in a state institution for people with severe disabilities: constructs of volunteerism and professionalism. Zhurnal issledovanii sotsial'noi politiki=Journal of Social Policy Studies, 2011, vol. 9, no. 3, pp. 391-416. Available at: https://cyberleninka.ru/article/n/dobrovoltsy-blagotvoritelnoy-organizatsii-vgosudarstvennom-uchrezhdenii-dlya-lyudey-s-tyazheloy-invalidnostyu-konstrukty/viewer (accessed June 1, 2021). (In Russ.).

3. Konzak D., Chernysheva O.M. The voluntary work in penitentiary establishments in Germany. Vestnik instituta: prestuplenie, nakazanie, ispravlenie=Institute Bulletin: Crime, Punishment, Correction, 2014, no. 3 (27), pp. 83-89. (In Russ.).

4. Korneeva E.L. The main directions of research volunteer activities. Psikhologicheskaya nauka i obrazovanie psyedu. $r u .=$ Psychological Science and Education psyedu.ru., 2015, vol. 7, no. 1, pp. 131-141. (In Russ.).

5. Nikovskaya L.I., Yakimets V.N. Public policy and civil society (case study of Saint Petersburg). Politicheskaya ekspertiza: POLITEKS=Political Expertise: POLITEX, 2018, vol. 14, no. 1, pp. 57-67. DOI 10.21638/11701/spbu23.2018.105. Available at: $\quad$ https://cyberleninka.ru/article/n/publichnaya-politika-i-grazhdanskoe-obschestvo-sankt-peterburgskiy-keys (accessed June 1, 2021). (In Russ.).

6. Ol'khovik N.V. The effectiveness of criminal punishment without a deprivation of liberty. Vserossiiskii kriminologicheskii zhurnal=Russian Journal of Criminology, 2018, vol. 12, no. 1, pp. 51-59. (In Russ.).

7. Pevnaya M.V. Volonterstvo kak sotsial'nyi fenomen: upravlencheskii podkhod: avtoreferat dissertatsii na soiskanie uchenoi stepeni doktora sotsiologicheskikh nauk [Volunteering as a social phenomenon: a managerial approach: Doctor of Sciences (Sociology) dissertation abstract]. Nizhny Novgorod, 2016. 42 p.

8. Saralieva Z.Kh. Innovative social macro-, meso-, and microtechnologies. Vestnik Nizhegorodskogo universiteta im. N.I. Lobachevskogo=Vestnik of Lobachevsky University of Nizhni Novgorod, 2013, no. 3-3, pp. 229-234. (In Russ.).

9. Saralieva Z.Kh. Specifics of professional activity of social workers. In: Saralieva Z.Kh. (Ed.). Sotsial'nye innovatsii v razvitii trudovykh otnoshenii i zanyatosti $v$ XXI veke: materialy mezhdunarodnoi nauchno-prakticheskoi konferentsii [Social innovations in the development of labor relations and employment in the 21st century: proceedings of the international scientific and practical conference]. Nizhny Novgorod: NISOTs, 2014. Pp. 795-798. (In Russ.).

10. Sikorskaya L.E. Organizatsiya dobrovol'cheskoi deyatel'nosti v gorodskoi srede: uchebno-metodicheskoe posobie [Organizing volunteer activity in the urban environment: an educational and methodological manual]. Moscow: Nats. in-t biznesa, 2008. 212 p.

11. Sokolov A.V., Vlasova A.A. Volunteer resource for the development of society. Vlast'=Power, 2014, vol. 22, no. 11, pp. 110-115. Available at: https://cyberleninka.ru/article/n/dobrovolcheskiy-resurs-razvitiya-obschestva (accessed June 1, 2021). (In Russ.)

12. Tarasova N.V. Volunteer activity as a historical and pedagogical phenomenon. Pedagogicheskoe obrazovanie v Rossii=Pedagogical Education in Russia, 2012, no. 4, pp. 46-52. Available at: https://cyberleninka.ru/article/n/ volonterskaya-deyatelnost-kak-istoriko-pedagogicheskiy-fenomen (accessed June 1, 2021). (In Russ.).

13. Timets M.V., Gibadulinova L.R. Constitutional foundations of volunteer activity in the Russian Federation. Uspekhi v khimii $i$ khimicheskoi tekhnologii=Advances in Chemistry and Chemical Technology, 2015, no. 5, pp. 82-84. (In Russ.).

14. Kholina O.I. Institualizatsiya volonterstva v strukturu rossiiskogo grazhdanskogo obshchestva: dissertatsiya na soiskanie uchenoi stepeni kandidata sotsiologicheskikh nauk [Institutionalization of volunteerism in the structure of Russian civil society: Candidate of Sciences (Sociology) dissertation]. Krasnodar, 2012. 132 p. 
15. Jakobson L.I., Mersiyanova I.V., Kononykhina O.N. et al. Civil society in modernising Russia: analytical report of The Centre for Studies of Civil Society and the Non-for-Profit Sector of the National Research University "Higher School of Economics" according to the results of a "Civil Society Index - CIVICUS" project. Moscow: NRU HSE, 2011. 48 p.

16. Goodman A. Rehabilitating and Resettling Offenders in the Community. Hoboken, New Jersey: John Wiley \& Sons Ltd, 2012. 249 p.

17. Jakobson L., Leonard C., Nazarov Z. Do voluntary associations matter for the spread of civic activism in Russia? Matching technique applied to survey data. Social Science Quarterly, 2020, vol. 101, no. 1, pp. 183-200. DOI 10.1111/ssqu.12726. 18. Kampen T., Tonkens E. Empowerment and disempowerment of workfare volunteers: a diachronic approach to activation policy in the Netherlands. Social Policy and Society, 2019, vol. 18, no. 3, pp. 351-364.

\section{INFORMATION ABOUT THE AUTHORS}

SERGEI L. BABAYAN - Doctor of Sciences (Law), Chief Researcher at Scientific Research Center-2, Research Institute of FSIN Russia, Moscow, Russian Federation, professor at the Department of Penal Law and Organization of Educational Work with Convicts, Faculty of Law, Vologda Institute of Law and Economics of FSIN Russia, Vologda, Russian Federation. ORCID: https://orcid.org/0000-0001-8712-0192, e-mail: bsI09@mail.ru

NIKOLAI V. OL'KHOVIK - Candidate of Sciences (Law), Leading Researcher at Scientific Research Center-2, Research Institute of FSIN Russia, Moscow, Russian Federation, associate professor at the Department of Criminal Law, National Research Tomsk State University, Tomsk, Russian Federation. ORCID: https://orcid.org/0000-0002-7150-7234, e-mail: lawtsu@rambler.ru

SVETLANA A. FADEEVA - Doctor of Sciences (Pedagogy), Professor, Chief Researcher at Scientific Research Center-2, Research Institute of FSIN Russia, Moscow, Russian Federation, professor at the Department of the Theory and Practice of Education and Additional Training, Nizhny Novgorod Institute for Education Development, Nizhny Novgorod, Russian Federation. ORCID: https://orcid.org/0000-0002-7150-7234, e-mail: fadeeva1607@gmail.com

IRINA A. LAKINA - Researcher at Scientific Research Center-3, Research Institute of FSIN Russia, Moscow, Russian Federation. ORCID: https://orcid.org/0000-0002-5342-2886, e-mail: shumik.88@mail.ru

LIDIYA P. PITKEVICH - Researcher at Scientific Research Center-1, Research Institute of FSIN Russia, Moscow, Russian Federation. ORCID: https://orcid.org/0000-0003-2040-0960, e-mail: Lida-19832008@yandex.ru 